\section{Manual and Rotary Instrumentation Ability to Reduce Enterococcus faecalis Associated with Photodynamic Therapy in Deciduous Molars}

Sérgio Luiz Pinheiro, Josianne Neres da Silva, Rafael Orro Gonçalves, Karina

Teixeira Villalpando
PUC - Pontifical Catholic University of Campinas, Campinas, SP, Brazil

Correspondence: Prof. Dr. Sérgio Luiz Pinheiro: Rua Raul Gasparini, 525, 13280-000 Vinhedo, SP, Brasil. Tel: +55-11-99245-0090. e-mail:slpinho@puc-campinas.edu.br

\begin{abstract}
This aim of this study was to assess the ability of manual or rotary instrumentation associated with photodynamic therapy (PDT) to reduce Enterococcus faecalis using three combinations of light/photosensitizers: toluidine blue 0/laser, fuchsin/halogen light and fuchsin/LED. Twenty deciduous molars were selected and contaminated with Enterococcus faecalis (McFarland 0.5 scale). Working length determination was performed by visual method. The teeth were randomly divided into two groups: $\mathrm{G} 1(\mathrm{n}=10)$ : manual instrumentation (Kerr-type files) and G2 $(n=10)$ : rotary instrumentation (ProTaper system). The bacteria were collected three times using sterile paper cones compatible with the anatomic diameter of the root canal for $30 \mathrm{~s}$ before and after instrumentation and after PDT. The samples were diluted in peptone water, seeded on blood agar plates and incubated in an oven at $37{ }^{\circ} \mathrm{C}$ for colony-forming units counting. The decrease of $E$. faecalis counts after instrumentation and after PDT was compared using the Wilcoxon test, t-test and Kruskal Wallis test. A significant reduction of $E$. faecalis occurred after manual and rotary instrumentation and after PDT using the three combinations of light/ photosensitizer $(p<0.05)$. It may be concluded that both rotary and manual instrumentation reduced $E$. faecalis. Fuchsin with halogen light or LED irradiation and toluidine blue 0 with laser irradiation can be used to reduce $E$. faecalis in root canals of primary molars. PDT can be used as an adjuvant to conventional endodontic treatment.
\end{abstract}

Key Words: endodontic treatment, manual instrumentation, rotary instrumentation, deciduous teeth, photodynamic therapy.

\section{Introduction}

The major cause of occlusal problems in permanent dentition is the early loss of deciduous teeth. Deciduous dentition is a guide for the correct eruption of permanent teeth. Early loss of deciduous teeth may cause important problems such as: respiratory/phonation dysfunctions, perioral muscle hypotonia, delay and malocclusion of permanent dentition (1). Traumatic injuries, especially in anterior teeth, have a high prevalence and are considered serious problems because of the pulp involvement and the emotional aspect for the patient and parents. The maintenance of primary teeth with pulp changes caused by caries or trauma is a major therapeutic challenge in pediatric dentistry because of the pulp's biological cycle and the internal anatomy of these teeth. Therefore, root canal sanitizers with good performance in eliminating bacterial contamination are a key to treatment success in such teeth $(2,3)$.

The most widely used technique for endodontic treatment of deciduous teeth is performed with carbon steel hand files. This technique is widely used due to its low cost (4). Chemical-mechanical instrumentation reduces the number of microorganisms in the root canals (5). However, even after instrumentation the residual bacteria may result in endodontic treatment failure due to recolonization of the root canal system (6). The main microorganism responsible for this process is the Enterococcus faecalis (7).

The literature has suggested alternative therapies to be used after instrumentation, including PDT, with the purpose of reducing residual bacteria in root canals. This method proposes that a light with a specific wavelength on a photosensitizer produces energy photons that release free radicals and singlet oxygen. These substances act on the bacterial wall modifying the metabolism by altering lipids, proteins and nucleic acids, leading to bacterial death. Furthermore, this technique is easily applied, painless, and it does not promote microbial resistance or cause systemic effects (8-12).

The halogen-type lamps, the light-emitting diode (LED) lamps and low-intensity laser radiation may all be used with photosensitizers (13). Halogen lamps produce blue light, release heat when activated and have a wavelength of approximately $670 \mathrm{~nm}$. Light-emitting diode lamps have a set of several mini-lamps that emit monochromatic light with low temperature elevation at a wavelength ranging from 450-490 $\mathrm{nm}$ (14). Low-intensity laser has a wavelength of approximately $638 \mathrm{~nm}$, and presents analgesic, anti-inflammatory and regenerative effects. 
Furthermore, when associated with a photosensitizer, it has antimicrobial action (11)

Several photosensitizers may be used in PDT. Among them, the xanthines and phenothiazines are the most common (7-12). Fuchsin identifies caries lesion and bacterial plaque, has low cost and can be used in PDT. This photosensitizer can be classified as belonging to the xanthine group and may be irradiated by blue light. However, no studies in the literature have assessed fuchsin as a photosensitizer to reduce $E$. faecalis in deciduous molars. Thus, the aim of this study was to assess the ability of manual or rotary instrumentation associated with photodynamic therapy (PDT) to reduce E. faecalis using three combinations of light/photosensitizers: toluidine blue O/laser, fuchsin/halogen light and fuchsin/LED.

\section{Material and Methods}

The study was approved by the institutional Research Ethics Committee (Protocol \#783/09).

\section{Sample Selection}

Twenty primary molars were obtained from the Pediatric Clinic of the Pontifical Catholic University of Campinas, Brazil with the consent of parents and/or guardians by signing a tooth donation form. The inclusion criteria were as follows: primary molars with at least $2 / 3$ of root; absence of internal or external pathological root resorption; absence of internal and/or external perforation in the furcation area; moderate root angulation (curvature radius between 10 to $20 \mathrm{~mm}$ and angle between $25^{\circ}$ and $39^{\circ}$ ) (15). The following exclusion criteria were considered: primary molars with less than $2 / 3$ of root; teeth with internal or external pathological root resorption; presence of internal and/or external perforation in the furcation area; teeth without curvature radius between 10 to $20 \mathrm{~mm}$ and angle between $25^{\circ}$ and $39^{\circ}(15)$.

A cross-section was made in the cementoenamel junction to separate the crown from the root using a double-faced carburil disk (KG Sorensen, Agerskov, Denmark). Irrigation was done with saline and the root canal length was established by inserting a \#10 Kerr hand file (Dentsply Maillefer, Ballaigues, Switzerland) in the root canal until the active tip was seen in the apical foramen (visual method). The instrument was withdrawn and the working length was determined by subtracting $1 \mathrm{~mm}$ from the length of the canal $(16,17)$. To help the contamination of the root canal system with $E$. faecalis, initial instrumentation was performed with the \#10 hand file up to the working length (2).

The teeth were sterilized in humid heat autoclave at $212{ }^{\circ} \mathrm{C}$ for $15 \mathrm{~min}$. The contamination of the root canals was performed with a standard strain of E. faecalis ACT 19433 (Labcenter, Campinas, SP, Brazil) at a 0.5 McFarland scale. Each root canal was irrigated with $1 \mathrm{~mL}$ of standard strain of $E$. faecalis in laminar flow using a $5 \mathrm{~mL}$ syringe (BD Plastipak, Curitiba, PR, Brazil) and needle (BD Plastipak). The contaminated specimens were transferred to a sterile receptacle containing a standard strain and $\mathrm{BHI}$. Samples were inoculated in anaerobic jars (Oxoid Inc., Basingstoke, Hampshire, UK) at $37{ }^{\circ} \mathrm{C}$ for $24 \mathrm{~h}$ in an atmosphere of $85 \% \mathrm{~N}_{2}, 10 \% \mathrm{CO}_{2}$ and $5 \% \mathrm{H}_{2}$ obtained by using anaerobic envelope and anaerobic indicators (Anaerogen ${ }^{\mathrm{TM}}{ }^{\mathrm{N}}$, Oxoid Inc.) for 21 days. Every 2 days, $20 \mu \mathrm{L}$ of BHI broth were added using a 0.3 cc insulin syringe.

A sterile paper cone (Les Fils D'Auguste Maillefer, Ballaigues, Switzerland) compatible with the anatomic diameter of the canal was introduced in each root canal for 30 s obtaining the first sample of bacterial contamination that was immediately transferred to test tubes containing $4.5 \mathrm{~mL}$ of BHI (Brain Heart Infusion-sterile; Acumedia Manufacturers, Lansing, MI, USA). Canals were instrumented by a single operator and the teeth were randomly divided into 2 groups $\mathrm{G} 1(\mathrm{n}=10)$ : manual instrumentation using Kerr-type files (Les Fils D'Auguste Maillefer) according to the crown-down technique; in the mesial or buccal canals, files sizes 30 and 25 were used to prepare the cervical third and sizes 20 and 15 to prepare the middle and apical thirds; in the distal or palatal canal, files sizes 45 and 40 were used in cervical third and sizes 30 and 25 in the middle and apical thirds (17). $G 2(n=10)$ : rotary instrumentation using the ProTaper system activated by the rotary engine-driven motor X-Smart (LesFils D'Auguste Maillefer) [files S1 and S2 (300 rpm and $3 \mathrm{~N}$ torque) and files $\mathrm{F} 1$ and F2 (300 rpm and 2 $\mathrm{N}$ torque)] $(17,18)$. In all groups, the canals were debrided respecting the safety zone areas of the
Table 1. Types of light, power, wavelength, dose, and duration of application

\begin{tabular}{lccc}
\hline Light & Laser & Halogen light & Led \\
\hline $\begin{array}{l}\text { Brand name, } \\
\text { manufacturer }\end{array}$ & $\begin{array}{c}\text { Flash Lase III (DMC, } \\
\text { Ribeirão Preto, SP, Brazil) }\end{array}$ & $\begin{array}{c}\text { XL 3000 (3M, } \\
\text { Sumaré, SP, Brazil) }\end{array}$ & $\begin{array}{c}\text { Litex 6955 } \\
\text { City of (Dentamerica }\end{array}$ \\
Power & $4 \mathrm{~J} / \mathrm{cm}^{2}$ & $38.28 \mathrm{~J} / \mathrm{cm}^{2}$ & $30.48 \mathrm{~J} / \mathrm{cm}^{2}$ \\
Wavelength & $660 \mathrm{~nm}$ & $670 \mathrm{~nm}$ & $470 \mathrm{~nm}$ \\
Dose applied & $100 \mathrm{~mW}$ & $638 \mathrm{~mW}$ & $508 \mathrm{~mW}$ \\
Duration of application & $60 \mathrm{~s}$ & $60 \mathrm{~s}$ & $60 \mathrm{~s}$ \\
\hline
\end{tabular}


root. At each change of file, the root canals were irrigated with $1 \mathrm{~mL}$ of $1 \% \mathrm{NaOCl}$. After instrumentation, a new collection was made using sterile paper cones.

To perform photodynamic therapy, 30 root canals of ten deciduous molars (manual or rotatory instrumentation) were randomly distributed according to 3 different treatments, so that in each group of photodynamic therapy ten root canals were used. The root canals were randomly distributed according to 3 different treatments: toluidine blue 0/low-intensity laser, fuchsin/LED and fuchsin/halogen light (Table 1). During PDT, the photosensitizer $(0.005 \%$ concentration) was inserted into the canals with sterile paper cones and the duration of pre-irradiation was 3 min.

For the three different types of treatment the photosensitizer was applied with the aid of clinical tweezers and sterile paper cones compatible with the root canal. The sterile paper cone was placed in a dappen dish containing a photosensitizer solution. After complete soaking of the paper cone, it was transferred to the previously drawn canal and left there for three minutes (duration of preirradiation). For light application, the tip of the device was

\begin{tabular}{|c|c|c|c|}
\hline Technique & Before & After & $p$ value \\
\hline Manual & $3.22(1.46)^{\mathrm{a}}$ & $0.53(1.27)^{\mathrm{b}}$ & 0.0007 \\
\hline Rotary & $3.80(1.11)^{\mathrm{a}}$ & $1.33(1.77)^{\mathrm{b}}$ & 0.0007 \\
\hline $\mathrm{p}$ value & 0.2347 & 0.1683 & \\
\hline
\end{tabular}

Different letters in the horizontal: $p<0.01$; equal letters in the vertical: p>0.05; Ml: manual instrumentation: Rl rotary instrumentation.

Table 3. Arithmetic means, standard deviations, Wilcoxon test (horizontal) and Kruskal Wallis test (vertical) of the variation of Enterococcus faecalis in root canals of deciduous teeth before and after photodynamic therapy, using manual and rotary instrumentation $\left(\log _{10}\right)$

\begin{tabular}{lcccc}
\hline Technique & Combinations & Before PDT & After PDT & p value \\
\hline & TB+L & $4.71(0.83)^{\mathrm{a}}$ & $0.92(1.71)^{\mathrm{b}}$ & 0.0117 \\
$\begin{array}{l}\text { Manual } \\
\text { instrumentation }\end{array}$ & $\mathrm{F}+\mathrm{HL}$ & $4.53(1.10)^{\mathrm{a}}$ & $0.51(1.35)^{\mathrm{b}}$ & 0.0180 \\
& $\mathrm{~F}+\mathrm{LED}$ & $4.30(1.16)^{\mathrm{a}}$ & $0.00(0.00)^{\mathrm{b}}$ & 0.0077 \\
& $\mathrm{p}$ value & 0.8661 & 0.6609 & \\
& & & & \\
Rotary & $\mathrm{TB}+\mathrm{L}$ & $5.94(0.50)^{\mathrm{a}}$ & $2.23(2.41)^{\mathrm{b}}$ & 0.0051 \\
instrumentation & $\mathrm{F}+\mathrm{HL}$ & $4.67(1.73)^{\mathrm{a}}$ & $0.00(0.00)^{\mathrm{b}}$ & 0.0051 \\
& $\mathrm{~F}+\mathrm{LED}$ & $5.42(0.55)^{\mathrm{a}}$ & $0.91(1.95)^{\mathrm{b}}$ & 0.0051 \\
& $\mathrm{p}$ value & 0.0709 & 0.1590 & \\
\hline
\end{tabular}

Different letters in the horizontal: $p<0.05$; equal letters in the vertical: $p>0.05$; $\mathrm{TB}+\mathrm{L}$ : toluidine blue 0 and laser; F + HL: fuchsin and halogen light, F + LED: fuchsin + LED. as close as possible to the root canal entrance to enlarge the amount of sensitized area. The application of each type of light was done similarly: light application for $1 \mathrm{~min}$. After PDT, the third microbiological collection was performed inserting a sterile paper cone compatible with the canal, which was left in contact with the canal walls for $30 \mathrm{~s}$.

\section{Microbiological Procedures - Determination of Total Viable Bacteria}

The collected samples were diluted, seeded and cultivated in the Microbiology Laboratory of PUCCampinas. Homogenization was performed for $3 \mathrm{~min}$ in a tube agitator (Phoenix, Araraquara, SP, Brazil). Immediately after homogenization, six-fold dilutions were done in sterile peptone water (Himedia Laboratories, Mumbai, India) and sowing was performed using three aliquots seeded with a micropipette onto the surface of blood agar plates. At each dilution, homogenization was performed for $30 \mathrm{~s}$. The plates were incubated in anaerobic jars (Oxoid Inc.) at $37^{\circ} \mathrm{C}$ for 5 days in an atmosphere of $85 \% \mathrm{~N}_{2}, 10 \% \mathrm{CO}_{2}$ and $5 \% \mathrm{H}_{2}$ obtained using anaerobic generator envelopes (AnaerogenTM, Oxoid Inc.). The total count of viable bacteria was performed using a colony counter (Phoenix).

\section{Statistical Analysis}

The results were analyzed statistically by the Biostat 4.0 software. The decrease of $E$. faecalis counts after instrumentation and after performing PDT was compared using the Wilcoxon test, t-test and Kruskal Wallis test.

\section{Results}

There was significant reduction of $E$. faecalis after manual and rotary instrumentation of the root canals of deciduous teeth $(p<0.01)$. There was no difference in the reduction of $E$. faecalis between the two instrumentation techniques (Table 2).

Photodynamic therapy using toluidine blue 0 combined with laser, fuchsin associated with halogen light, and fuchsin combined with LED resulted in significant reduction of $E$. faecalis in the root canals of deciduous teeth after manual $(p<0.05)$ or rotary $(p<0.01)$ instrumentation. No significant difference in the reduction of E. faecalis was found among the three PDT techniques ( $p>0.05$ ) (Table 3 ).

\section{Discussion}

The maintenance of primary teeth until the occurrence of physiological exfoliation contributes to mastication, 
phonation, esthetics, and prevents deleterious habits of the child (1). Therefore, maintaining deciduous teeth in the oral cavity until physiological exfoliation is important. Pulp changes caused by caries or trauma are the most common indication for endodontic treatment. The success of endodontic treatment in deciduous teeth depends on significant microbial reduction after chemical-mechanical instrumentation. However, the amount of residual bacteria in the root canal after chemical-mechanical instrumentation is significant and may lead to new infection in the root canal (21).

Endodontic treatment failure may also be associated with the anatomic variation in the curvature and diameter of root canals or failure of the surgical technique (11). In endodontic treatment of deciduous teeth, in addition to the difficulty of debriding the root canal system because of the secondary canals, accessories and root resorption, the child may not have the psychological maturity to cooperate during treatment (6).

The literature reports that even after chemicalmechanical instrumentation there are still residual bacteria in the root canal capable of re-colonizing it, such as the gram-positive Streptococcus sp and E. faecalis (11). E. faecalis is resistant to intracanal medication used between the appointments and to chemicals used during instrumentation (10). There are no studies in the literature that report the presence of $E$. faecalis after instrumentation using the Profile, Race and FKG systems. The present study performed the contamination of root canals of deciduous teeth with a standard strain of E. faecalis - microorganism resistant to chemomechanical instrumentation of the root canal system $(5,11)$.

Chemomechanical preparation for disinfecting root canals of deciduous teeth may be performed using the manual technique with K-files or a rotary system with nickel-titanium files (21). Manual instrumentation is widely used in deciduous teeth, but there are limitations as regards the cleaning quality of the root canals (4). The results of the present study showed a reduction of $83.54 \%$ in the number of viable bacteria after manual instrumentation, which is in agreement with the literature (8). Although the manual technique shows a high potential for microbial reduction, the number of viable bacteria after instrumentation is significant (8). In this study, $16.46 \%$ root canals were contaminated after manual instrumentation.

The nickel-titanium files have several advantages over the manual files: radial guide, smear plug removal from dentin during instrumentation and shorter operative time (20). Assessing the removal of debris and smear layer after instrumentation with FlexMaster, Race and NiTiflex K-file, the rotary instrumentation with FlexMaster and Race presented less formation of smear layer after instrumentation (20). Some authors have compared following the different types of files: Profile, Race and FKG, assessing the percentage of microbial reduction for each set of files and found microbial reduction for all the sets (5). The results of this study are in agreement with those studies in the literature, since microbial reduction of $E$. faecalis was significant (71.62\%) after instrumentation with the ProTaper system (5).

In this study, no chelating solution was used to remove smear layer because there is no scientific evidence to support this indication in endodontic treatment for primary teeth. The use of EDTA, for example, could promote injuries in periapical tissue because deciduous teeth have resorption areas and presence of accessory foramina. However, EDTA can remove smear layer and debris after instrumentation, causing bacteria reduction and may improve the photosensitizer action in PDT of deciduous teeth. New studies must be performed to evaluate the solution to remove smear layer in deciduous teeth.

PDT uses light and a photosensitizer, which is usually exogenous, and which combined produce the chemical reactions leading to cell death (12). The photons in light radiation are absorbed by the photosensitizer resulting in the production of singlet oxygen (7-11). The PDT is factor-dependent on the type of bacteria, timing and the manner of irradiation of the root canal (6). During this reaction, light irradiation without heat generation, such as that of the laser and LED, is unable to cause injury to the surrounding tissues of the root canal and the reaction is athermal (10). One advantage of the photodynamic therapy is the non-induction of bacterial resistance.

According to Muhammad et al. (22), photodynamic therapy using non-collimated light and an optimized concentration of photosensitizing agent in permanent teeth may have a role in disrupting the biofilm and decreasing the bacterial load to intact microbial biofilm; these effects are statistically inferior to those obtained by passive ultrasonic irrigation. Zand et al. (23) observed that photodynamic therapy and the $2.5 \% \mathrm{NaOCL}$ solution were equally efficient in completely eliminating $E$. faecalis in young, mature and old biofilms using 120 permanent human maxillary and mandibular central incisors. Sabino et al. (24) contaminated ten permanent third molar with a bioluminescent strain of C. albicans and introduced into the canals blue methylene and irradiated with laser tip either in contact with pulp chamber or within the canal using an optical diffusion fiber. Sabino et al. (24) observed that both light delivery systems performed significant fungal inactivation, but when irradiation was performed with an optical diffusion fiber, microbial burden reduction was nearly 100 times more effective. Siddiqui et al. (25) performed a systematic literature review and observed that $70 \%$ of the studies that 
fulfilled their eligibility criteria showed that PDT is more efficient in eliminating $E$. faecalis in infected root canals than conventional endodontic therapy and that there was an inconsistency in the methodology and laser parameters used in those studies.

The photosensitizers are divided into two large groups: xanthine derivatives such as erythrosine, rose bengal and eosin; and phenothiazine derivatives such as azulene, methylene and toluidine blue. Previous studies used several types of photosensitizers at different concentrations $(7,9,11)$. Normally, most photosensitizers are not available in the dental office. Fuchsin is a low-cost dye, available in the dental office, and it is used to show caries lesion and bacterial plaque. In addition to the toluidine blue photosensitizer, the aim of this study was to assess the applicability of fuchsin as a photosensitizer for PDT in root canals of deciduous molars. According to this study, three different forms of application of PDT cause a significant reduction of $E$. faecalis.

Toluidine blue 0 (TBO) is a photosensitizer that provides interaction and it is capable of penetrating the cell membrane of bacteria causing increased susceptibility to light absorption. TBO is a photosensitizer derived from phenothiazines. It has affinity for the outer membrane of gram-positive bacteria and lipopolysaccharides of gram-negative bacteria. TBO plus laser irradiation causes chemical reactions that significantly reduce the number of viable bacteria by releasing singlet oxygen and toxic free radicals to the bacteria in the canal. The variation in intensity or exposure time, as well as the concentration of the photosensitizer and duration of pre-irradiation, causes greater or lesser microbial reduction. Pinheiro et al. (8) observed reduction of $98.37 \%$ total bacteria viable after photodynamic therapy in deciduous teeth with necrotic pulp using low-intensity diode together with toluidine blue, in agreement with the results of this research that observed photodynamic therapy using the same photosensitizer and laser and resulted in significant reduction of E. faecalis in the root canals of deciduous molars.

Xanthines are cyclic anionic compounds with three aromatic rings in linear arrangement with an oxygen atom in the central ring, which contain fluorescein, eosin, erythrosin and rose bengal. Photocatalytic conversion of these photosensitizers easily converts triplet oxygen into singlet oxygen. The singlet oxygen causes damage to the fatty acids in the lipid membranes, which undergo peroxidation reactions of enzymes by specific reactions with the methionine, tryptophan, tyrosine amino acids, and nucleic acids, resulting in bacterial death. The present study assessed fuchsin as a photosensitizer and found similar microbial reduction of $E$. faecalis when compared with the blue photosensitizers.
It may be concluded that both rotary and manual instrumentation reduced $E$. faecalis. For all combinations of light/photosensitizer assessed in this study, a reduction in the number of $E$. faecalis was found. Thus, the photosensitizer derived from phenothiazine and xanthines irradiated with blue or red light, respectively, are an option to help microbial reduction in root canals of deciduous molars.

\section{Resumo}

0 objetivo do presente estudo foi avaliar a redução de Enterococcus faecalis após instrumentação manual ou rotatória associada à terapia fotodinâmica (PDT) utilizando 3 combinações luz/fotossensibilizante: azul de toluidina O/laser, fucsina/luz halógena e fucsina/LED. Foram selecionados 20 molares decíduos que foram contaminados com Enterococcus faecalis (escala 0,5 de McFarland). A odontometria foi feita através do método visual. Os dentes foram divididos aleatoriamente em dois grupos: $\mathrm{G} 1$ ( $n=10)$ : instrumentação manual (limas tipo Kerr) e G2 $(n=10)$ : instrumentação rotatória (sistema ProTaper). Foram realizadas coletas com cone de papel estéril compatível com o diâmetro anatômico do canal durante $30 \mathrm{~s}$ antes e após a instrumentação e a PDT. As amostras foram diluidas em água peptonada, semeadas em placas de agar-sangue e incubadas em estufa a $37^{\circ} \mathrm{C}$ para contagem das unidades formadoras de colônias. As comparações antes da redução de E. faecalis após a instrumentação e após a realização da PDT foram realizadas pelo teste de Wilcoxon, teste t e Kruskal Wallis. Houve redução significante de $E$. faecalis após a instrumentação manual ou rotatória e após realização da PDT com as três combinações de luz/fotossensibilizante $(p<0,05)$. Pode-se concluir que a instrumentação rotatória e manual acarretou a redução de $E$. faecalis. A fucsina irradiada com luz halógena ou led e o azul de toluidina irradiado com laser podem ser utilizados para redução de $E$. faecalis do sistema de canais radiculares de molares decíduos. A terapia fotodinâmica pode ser utilizada como coadjuvante ao tratamento endodôntico convencional.

\section{References}

1. Farsi NM, Alamoudi N. Relationship between premature loss of primary teeth and the development of temporomandibular disorders in children. Int J Paediatr Dent 2000;10:57-62.

2. Leonardo MR, Silva LA, Nelson-Filho P, Silva RA, Raffaini MS. Ex vivo evaluation of the accuracy of two electronic apex locators during root canal length determination in primary teeth. Int Endod J 2008;41:317321.

3. Sant'Anna GR. Photodynamic therapy for the endodontic treatment of a traumatic primary tooth in a diabetic patient. J Dent Res Dent Clin Dent Prospect 2014;8:56-60.

4. Da Silva LA, Nelson-Filho P, Faria G, Souza-Gugelmin MCM, Yto IY. Bacterial profile in primary teeth with necrotic pulp and periapical lesions. Braz Dent J 2006;17:144-148.

5. Moghaddam KN, Owlia P, Baghalian A. A comparison of Profile, Race and FKG systems in eliminating Enterococcus faecalis from the apical third of mandibular premolars. J Dent 2006;3:184-189.

6. Pinheiro SL, Schenka $A A$, Neto $A A$, de Souza $C P$, Rodriguez HM, Ribeiro MC. Photodynamic therapy in endodontic treatment of deciduous teeth. Lasers Med Sci 2009;24:521-526.

7. Garcez AS, Ribeiro MS, Tegos GP, Núñez SC, Jorge AO, Hamblin MR. Antimicrobial photodynamic therapy combined with conventional endodontic treatment to eliminate root canal biofilm infection. Lasers Surg Med 2007;39:59-66.

8. Pinheiro SL, Donegá JM, Seabra LM, Adabo MD, Lopes T, do Carmo TH, et al.. Capacity of photodynamic therapy for microbial reduction in periodontal pockets. Lasers Med Sci 2010;25:87-91.

9. Sahu K, Bansal H, Mukherjee C, Sharma M, Gupta PK. Atomic 
force microscopic study on morphological alterations induced by photodynamic action of Toluidine Blue 0 in Staphylococcus aureus and Escherichia coli. J Photochem Photobiol B 2009;96:9-16.

10. Komerik N, MacRobert AJ. Photodynamic therapy as an alternative antimicrobial modality for oral infections. J Environ Pathol Toxicol Oncol 2006;25:487-504.

11. Soukos NS, Chen PS, Morris JT, Ruggiero K, Abernethy AD, Som S, et al.. Photodynamic therapy for endodontic disinfection. J Endod 2006;32:979-984.

12. Krespi YP, Slatkine M, Marchenko M. Lethal photosensitization of oral pathogens via red-filtered halogen lamp. Protic J Oral Dis 2005;1:9295.

13. Wood S, Metcalf D, Devine D, Robinson C. Erythrosine is a potential photosensitizer for the photodynamic therapy of oral plaque biofilms. J Antimicrob Chemother 2006;57:680-684.

14. Mills RW, Uhl A, Jandt KD. Optical powers outputs, spectra and dental composite depths of cure, obtained with blue light emitting diode (LED) and halogen light curing units (LCUs). Br Dent J 2002;193:459-463.

15. Schneider SW. A comparison of canal preparations in straight and curved root canals. Oral Surg Oral Med Oral Pathol 1971;32:271-275.

16. Bernardes RA, Duarte MA, Vasconcelos BC, Moraes IG, Bernardineli $N$, Garcia $R B$, et al.. Evaluation of precision of length determination with 3 electronic apex locators: Root ZX, elements diagnostic unit and apex locator, and RomiAPEX D-30. Oral Surg Oral Med Oral Pathol Oral Radiol Endod 2007;104: 91-94.

17. Pinheiro SL, Araujo G, Bincelli I, Cunha R, Bueno C. Evaluation of cleaning capacity and instrumentation time of manual, hybrid and rotary instrumentation techniques in primary molars. Int Endod J 2012;45:379-385.

18. Machado ME, Sapia LA, Cai S, Martins GH, Nabeshima CK. Comparison of two rotary systems in root canal preparation regarding disinfection.
J Endod 2010;36:1238-1240.

19. Assed LBS, Nelson-Filho P, Faria G, Souza-Gugelmim MCM, Yoko II. Bacterial profile in primary teeth with necrotic pulp and periapical lesions. Braz Dent J 2006;17:144-148.

20. Zand V, Bidar M, Ghaziani P, Rahimi S, Shahi S. A comparative SEM investigation of the smear layer following preparation of root canals using nickel titanium rotary and hand instruments. J Oral Sci 2007;49:47-52.

21. Madan N, Rathnam MA, Shigli AL, Indushekar KR. K-files vs Profiles in cleaning capacity and instrumentation time in primary molar root canals: an in vitro study. J Indian Soc Pedod Prev Dent 2011;29:2-6.

22. Muhammad OH, Engineer MCR, Rocca JP, Brulat-Bouchard N, Medioni E. Photodynamic therapy versus ultrasonic irrigation: interaction with endodontic microbial biofilm, an ex vivo study. Photodiagnosis and Photodyn 2014;11:171-181.

23. Zand V, Milani AS, Amini M, Barhaghi MHS, Lotfi M, Rikhtegaran S, et al.. Antimicrobial efficacy of photodynamic therapy and sodium hypochlorite on monoculture biofilms of Enterococcus faecalis at different stages of development. Photomed Laser Surg 2014;32:245251.

24. Sabino CP, Garcez AS, Núñez SC, Ribeiro MS, Hamblin MR. Real-time evaluation of two light delivery systems for photodynamic disinfection of Candida albicans biofilm in curved root canals. Lasers Med Sci 2014 [Epub ahead of print. DOI 10.1007/S10103-014-1629-x].

25. Siddiqui $\mathrm{SH}$, Awan KH, Javed F. Bactericidal efficacy of photodynamic therapy against Enterococcus faecalis in infected root canals: A systematic literature review. Photodiagnosis and Photodyn Ther 2013;10:632-643.

Received February 25, 2014 Accepted October 23, 2014 